\title{
The Effect of Tax Reform in a Dynamic General Equilibrium Framework - Ramsey vs. Overlapping Generation Model
}

\author{
Ru-Min Liao ${ }^{1}$. \\ ${ }^{1} \mathrm{Ph} . \mathrm{D}$ Candidate in Public Finance, Institution of Public Finance, National Cheng-Chi University
}

\begin{abstract}
Based on a thorough comparison of the basic assumptions and economic underpinning of the Ramsey and over lapping generation (OLG) model, this study builds both static and dynamic computable general equilibrium tax policy models to analyze the effect of tax reform on Taiwan's economy. The new tax structure considers mainly a replacement of some parts of labor and capital income taxes by consumption tax. The benchmark year of the model is 2001, and the economy is divided into four sectors. The modeling framework is implemented on top of MPSGE, which is a special module within the General Algebraic Modeling System (GAMS). Our simulation results show differential outcomes for static and dynamic models. The slower speed of transition inherent in OLG model has caused variables such as welfare, capital stock, and replacement consumption tax rate change less than that in the Ramsey model when the tax reform policy is imposed. And the intergeneration effects of different tax burden between young and old generations can be found in the OLG model but not in the Ramsey model.
\end{abstract}

Keywords: Tax reform, Ramsey model, overlapping generation model, dynamic computable general equilibrium

\section{Introduction}

Current tax reform proposals discussed both in USA and Taiwan recently are raising the ratio of tax revenue for indirect tax and, at the same time, lowering the ratio for direct tax. For example, the flat tax reform in the U.S. has been focusing on replacing part of the tax base that originally from income by consumption.

Past studies discussing the effects of tax reform have been largely analyzed under the framework of the Ramsey model. For instance, Goulder and Summers (1989), Jorgenson (1996), and Jorgenson and Wilcoxen (1997) analyzed the effect of tax reform using a Ramsey-type model and found that total output, capital accumulation and labor supply levels could be increased through such a reform policy.

However, as Shelling (1995) criticized, the assumptions of an infinitely-lived agent are inappropriate in long-term policy issues. Heijdra et.al. (2006) also point out that altruistically link generations and view future generations as continuation of themselves will internalize intergenerational external effects, making it hard to study intergenerational issues.

In contrast of Ramsey model, OLG models allow simple demographic structure featuring different unlinked generations that coexist at any moment in time, which are more approaching the real word. Papers that have discussed tax reform issues using the OLG model include Auerbach and kotlikoff (1987), Auerbach (1997), Ventura (1999), Okamoto (2005), etc. They all find important differences from the infinite-horizon model, such as distributional effects across age cohorts. The OLG model results normally find that the consumption tax involves a "wealth hit," which imposed a tax on all existing assets, and especially on old cohorts. On the other hand, the consumption tax provides a windfall for all young and future generations because when the income (wage) tax is replaced, the tax burdens on young generations become lower and may be encouraged to supply labor. Such intergenerational distributional effects usually can not be found in Ramsey model.

In this paper, we first compare these two kinds of dynamic models' basic assumptions and their corresponding economic underpinnings as shown in Table1. Then, we construct a computable general equilibrium (CGE) tax policy model based on Taiwan's 2001 data. The database divides the economy into four industrial sectors (primary, manufacture, fundamental construction and services), and there are two primary factors (labor and capital) that facilitate the production in each sector. The database is used by three different model specifications, which are then used to perform policy simulations. Results from different specifications are then compared and policy implications are formulated.

\section{The Model}


In this paper, we use three different specifications of the model. The first is a static model, the second is a Ramsey model, and the third is an Overlapping generation (OLG) one. All these three models are constructed within the framework of Mathematical Programming System for General analysis (MPSGE; Rutherford, 1987) and are used to simulate the effects of a tax reform that consumption tax is specified to substitute for part of the labor income tax and capital income tax.

Most of the CGE models are solved as a standard optimization problem, which usually find the solutions by the method of Lagrange multiplier and is often solved as a non-linear programming (NLP) problem in GAMS. As Paltsev (2004) indicated, for cases with several consumers coexisting, taxes, or other distortions, will make it impossible to find market equilibrium as an optimization problem. In this case, the problem can be turned into a Mixed Complementary Problem (MCP) and solved as a system of non-linear equations. The NLP problems are the subset of MCP and by using MPSGE we can find an equilibrium as a solution to MCP.

MPSGE is a programming language designed for concise representing of Arrow-Debreu economic equilibrium models. Mathiesen (1985) has shown that Arrow-Debreu economic equilibrium model can be formulated as MCP, where a set of non-negative variables: prices, quantities and income that should be satisfied in terms of three classes of nonlinear inequalities when solved in MCP problem:

(1) Zero profit condition: any activity operated at a positive intensity must earn zero profit.

(2) Market clearance conditions: any good with positive price must have a balance between supply and demand and any good in excess supply must have a zero price

(3) Income balance condition: each agent's (including government) value of income must equal the value of factor endowments and tax revenue.

The MPSGE modeling framework is based on nested constant elasticity of substitution (CES) utility function and production functions. We do not require formulating an algebraic representation of production and utility functions. The data needed for a model include share, elasticity parameters, endowments and tax rates for all consumers and production sectors. MPSGE is especially useful when we meet some economic equilibrium models that are based on complicated functions such as nested CES. In this case, users of MPSGE need only to provide reference quantities, reference prices, and elasticity values. Merging MPSGE within the Generalized Algebraic Modeling System (GAMS) can reduce the setup cost of constructing an operational model and the cost of testing alternative specifications.

\section{Data and Results}

The input data of the constructed models are represented in the form of a balanced matrix, usually called Social Accounting Matrices (SAMs). The SAM can be described as a benchmark dataset for a specific year. In this paper, 2001 is the benchmark year for our analysis. The 2001 SAM for Taiwan is shown in Table 2. The entries of the SAM represent the outcomes of economic agents who interact among each other through prices that emerge from markets for good and factors of production. All the economic flows are accounted for, as the total sum of each row equal to the total sum of each column. The economic transactions happened remain a balance relationship and also means that there is a "sink" for every "source".

The tax reform policy simulations indicate that, using the consumption tax to substitute for the labor income tax will lead to a higher output level as compared to a tax substitution on the capital income tax in the static model. However, the reverse is found in the Ramsey and the OLG models. As the tax reform issues will not only influence the redistribution of income (or welfare) among people lived in that time, but also affect the future generations, the impact evaluation of the tax reform may be limited if only the single period comparative statistic model is used. As a result, the results from the dynamic models are more close to the real world.

Also, the magnitude of sectoral outputs and the increase of substituting consumption tax rate is higher in the Ramsey model than that in the OLG ones. That might be caused by the slower speed of transition property in the OLG models. By viewing the welfare change in the long-run, we also find that the substitution of capital income tax is better for older generations while substituting labor income tax is better for young and future generations. The intergenerational effects of different tax burdens between young and old generations will not be seen in the Ramsey model and can only be found in the OLG model analyses.

\section{References}

1. Auerbach, Alan J. and Laurence J. Kotlikoff (1987)'Dynamic Models of Taxation -Evaluating Fiscal Policy with a Dynamic Simulation Model" The 
American Economic Review, Vol. 77, No. 2, pp. 49-55.

2. Auerbach, Alan J. (1996) "Tax Reform, Capital Allocation, Efficiency and Growth." In Economic Effects of Fundamental Tax Reform, edited by Henry J. Aaron and William G. Gale. Washington, D.C. : The Brookings Institution.

3. Auerbach, Alan J.(1997)" The Future of Fundamental Tax Reform", The American Economic Review, Vol. 87, No. 2, pp.143-146

4. Ginsburgh, V., and M.A. Keyzer (1997)"'The structure of applied general equilibrium models, The MIT-Press.

5. Heijdra, Ben J.; Kooiman, Jan Peter; Ligthart, Jenny E.(2006)"'Environmental quality, the macro-economy, and intergenerational distribution" Resource and Energy Economics Volume: 28, Issue: 1, pp. 74-104

6. Jorgenson, Dale W.\& Peter J.Wilcoxen. (1990)"'Intertemporal General Equilibrium Modeling of U.S. Environmental Regulation" Journal of Policy Modeling. New York: Vol. 12, Iss. 4; p.715-744

7. Jorgenson, Dale W. (1996)"'The Agenda for U.S. Tax Reform", The Canadian Journal of Economics. Vol. 29, Special Issue: Part 2, pp. S649-S657

8. Jorgenson, Dale W. \& Peter J Wilcoxen.(1997)" The long-run dynamics of fundamental tax reform" The American Economic Review. Namshville: May 1997. Vol. 87, Iss. 2; p. $126-132$
9. Goulder, Lawrence H, \& Lawrence.H, Summers(1989)"Tax Policy, Asset Prices, and Growth - A General Equilibrium Analysis" Journal of Public Economics. Amsterdam: Apr 1989. Vol. 38, Iss. 3; p. 265-296

10. Mathiesen, L (1985)."Computation of Economic Equilibrium by a Sequence of Linear Complementarity Problems", Mathematical Programming Study, 23, 144-162.

11. Okamoto, Akira(2005)" Simulating progressive expenditure taxation in an aging Japan” , Journal of Policy Modeling Volume: 27, Issue: 3, pp. 309-325

12. Paltsev Sergey(2004)"Moving from Static to Dynamic General Equilibrium Economic Models (Notes for a beginner in MPSGE)"MIT Joint Program on the Science and Policy of Global Change, Technical Note No.4

13. Rutherford, Thomas. (1987) Applied General Equilibrium Modeling. PhD thesis, Stanford University

14. Schelling, Thomas C (1995)'Intergenerational discounting, "Energy Policy Volume: 23, Issue: 4-5, pp. 395-401

15. Ventura, Gustavo(1999)"Flat tax reform: A quantitative exploration", Journal of Economic Dynamics and Control Volume: 23, Issue: 9-10, pp. 1425-1458 
Table 1 Comparisons of two dynamic models

\begin{tabular}{|c|c|c|}
\hline Names & Dynastic (Ramsey) & Overlapping Generation(OLG) \\
\hline $\begin{array}{l}\text { Consumer's Utility } \\
\text { function }\end{array}$ & $U\left(C_{t}\right)=\sum_{t=0}^{\infty}\left(\frac{1}{1+\rho}\right)^{t} u\left(C_{t}\right)$ & $U\left(C_{1}, t\right)+\frac{1}{1+\rho} U\left(C_{2,} t+1\right), \rho \geq 0 \quad u^{\prime}>0 \quad u^{\prime \prime}<0$ \\
\hline Constraint & $\begin{array}{l}C_{t}+I_{t} \leq F\left(K_{t}, \overline{L_{t}}\right) \\
K_{t}=(1-\delta) K_{t-1}+I_{t-1}\end{array}$ & $\begin{array}{l}C_{1} t=W_{t}-S_{t} \\
C_{2} t+1=\left(1+r_{t+1}\right) S_{t}\end{array}$ \\
\hline Life length & Infinite lived consumers & $\begin{array}{l}\text { Finite lived consumers and generation } \\
\text { overlapped }\end{array}$ \\
\hline $\begin{array}{l}\text { Number of persons or } \\
\text { generation }\end{array}$ & $\begin{array}{l}\text { A finite number of persons or } \\
\text { maybe only one representative } \\
\text { agent }\end{array}$ & An infinite number of generation \\
\hline Altruistic motive & $\begin{array}{l}\text { Infinitely lived generations } \\
\text { anticipate each others' utility }\end{array}$ & $\begin{array}{l}\text { Seldom anticipate each others' utility especially } \\
\text { peoples in future }\end{array}$ \\
\hline Budget constraint & $\begin{array}{l}\text { Leave bequests to future } \\
\text { generation } \\
\text { Can borrow from future generation } \\
\text { Extend over the infinite horizon }\end{array}$ & $\begin{array}{l}\text { May leave bequests, but not often } \\
\text { Can not leave debt } \\
\text { Over consumer's lifetime only }\end{array}$ \\
\hline $\begin{array}{l}\text { Intergenerational } \\
\text { distribution effect }\end{array}$ & No discussing & Discussing equity and welfare change \\
\hline
\end{tabular}

Table 2001 SAM in Four Sectors of Taiwan in ten billion NTD

\begin{tabular}{|c|c|c|c|c|c|c|c|c|c|c|c|c|c|c|c|c|}
\hline & & A & B & C & D & $\mathbf{A}$ & B & C & D & Lab & Cap & Con & Gov & Inv & Row & $\begin{array}{l}\text { Row } \\
\text { Sum }\end{array}$ \\
\hline & & 1 & 2 & 3 & 4 & 5 & 6 & 7 & 8 & 9 & 10 & 11 & 12 & 13 & 14 & \\
\hline A & 1 & & & & & 513 & & & & & & & & & & 513 \\
\hline B & 2 & & & & & & 8590 & & & & & & & & & 8590 \\
\hline C & 3 & & & & & & & 2550 & & & & & & & & 2550 \\
\hline D & 4 & & & & & & & & 8347 & & & & & & & 8347 \\
\hline A & 5 & 82 & 546 & 107 & 2 & & & & & & & 183 & 0 & 0 & 48 & 968 \\
\hline B & 6 & 111 & 4715 & 668 & 292 & & & & & & & 1350 & 0 & 848 & 3817 & 11801 \\
\hline $\mathrm{C}$ & 7 & 17 & 423 & 326 & 301 & & & & & & & 499 & 0 & 802 & 330 & 2698 \\
\hline D & 8 & 59 & 1462 & 491 & 1159 & & & & & & & 3475 & 1404 & 161 & 626 & 8837 \\
\hline Labor & 9 & 143 & 1029 & 564 & 3061 & & & & & & & & & & & 4797 \\
\hline Capital & 10 & 101 & 415 & 394 & 3532 & & & & & & & & & & & 4442 \\
\hline Con & 11 & & & & & & & & & 4428 & 4194 & & -370 & & & 8252 \\
\hline Gov & 12 & & & & & 14 & 105 & 0 & 0 & 369 & 248 & & & & & 736 \\
\hline Inv & 13 & & & & & & & & & & & 2745 & -298 & & -636 & 1811 \\
\hline Row & 14 & & & & & 441 & 3106 & 148 & 490 & & & & & & & 4185 \\
\hline $\begin{array}{l}\text { Column } \\
\text { Sum }\end{array}$ & & 513 & 8590 & 2550 & 8347 & 968 & 11801 & 2698 & 8837 & 4797 & 4442 & 8252 & 736 & 1811 & 4185 & \\
\hline
\end{tabular}

Note: A: primary, B: manufacture, C: fundamental construction and D: services 